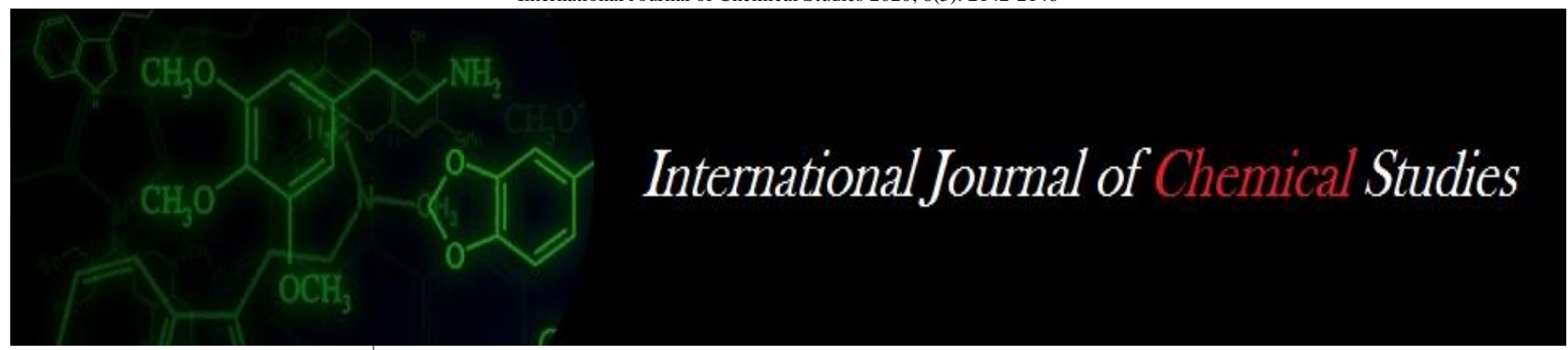

P-ISSN: 2349-8528

E-ISSN: 2321-4902

www.chemijournal.com

IJCS 2020; 8(3): 2142-2146

(C) 2020 IJCS

Received: 17-03-2020

Accepted: 21-04-2020

Indu Ganjeer

M.Tech., Department of

Agricultural Processing and

Food Engineering, SVCAET,

FAE \& RS, IGKV, Raipur,

Chhattisgarh, India

Chandrakali Banjare

Department of Soil \& Water

Engineering, SVCAET, FAE \&

RS, IGKV, Raipur,

Chhattisgarh, India

Corresponding Author: Chandrakali Banjare

Department of Soil \& Water

Engineering, SVCAET, FAE \&

RS, IGKV, Raipur,

Chhattisgarh, India

\section{Selection of suitable growing substrate for vegetable nursery production in a greenhouse}

\section{Indu Ganjeer and Chandrakali Banjare}

DOI: https://doi.org/10.22271/chemi.2020.v8.i3ad.9527

\begin{abstract}
The study was carried out in VNR Seeds Pvt. Ltd., in village Gomchi near Nandanvan of Raipur district in Chhattisgarh. Different substrates used are 100\% cocopeat, 100\% peatmoss, Mixture of 50\% cocopeat and $50 \%$ peat moss and mixture of $60 \%$ cocopeat and $40 \%$ vermiculite. After 25 days of seed sowing growth of seedlings in tray with $100 \%$ cocopeat we found that the average stem width $3.33 \mathrm{~mm}$, stem length $108 \mathrm{~mm}$, leaf width $42.33 \mathrm{~mm}$, and leaf length $56.66 \mathrm{~mm}$. In cocopeat the sturdy plant development is found. In $100 \%$ peat moss the result found is average stem width $3 \mathrm{~mm}$, stem length $91.33 \mathrm{~mm}$, leaf width $33 \mathrm{~mm}$ and leaf length $53.33 \mathrm{~mm}$ and in mixture of $50 \%$ cocopeat and 50\% peat moss, average stem width is $3.16 \mathrm{~mm}$, stem length $100.33 \mathrm{~mm}$, leaf width $42.33 \mathrm{~mm}$ and leaf length is $49.66 \mathrm{~mm}$. In mixture of $60 \%$ cocopeat and $40 \%$ peatmoss, average stem width is $2 \mathrm{~mm}$, stem length 64 $\mathrm{mm}$, leaf width $35.66 \mathrm{~mm}$ and leaf length is $48 \mathrm{~mm}$. These observation shows that growth of seedlings in tray with cocopeat is better in comparison to other substrates, therefore we considered as better growing substrate among all substrates we used.
\end{abstract}

Keywords: Cocopeat, leaf length, peat moss, seedlings, vermiculite

\section{Introduction}

Soil is the natural habitat for plants which supplies support, nutrients and water. However, where good soil is not available, where maintenance of favourable soil conditions is too expensive or where growth of high-value out-of-season crops is contemplated, there growing plants without fertile soil may be desirable. Good plant development depends to a large part on the growing medium used. The term 'growing medium' is amongst others used to describe the material used in a container to grow a plant. The terms 'substrate' (Schroeder, Sell, 2009; Vaughn et al., 2011) ${ }^{[2,15]}$ and 'rooting medium' (Blok, Verhagen, 2009) ${ }^{[4]}$ are also used as synonyms. Successful greenhouse and nursery production of container-grown plants is largely dependent on the chemical and physical properties of the growing media (Fitzpatrick, 2001; Wilson et al., 2003) ${ }^{[6,16]}$. If a plant develops a good root system in a well-balanced substrate, this does not mean that the plant is pampered and will not adapt to the harsh life outside a nursery. In fact, the opposite applies. To survive in the harsh environment of a field, often without additional watering and fertilizing, a plant needs a well-developed and strong root system.

Nursery crop production is among the fastest growing agricultural sectors. Nursery production inside a greenhouse is increasing day by day. But with the increase in production many of the problems that have been reported in the formulation of growing substrates were related to salt concentrations, water retention and nutrient release rates, all of which are critical in crop production. Therefore for a particular crop a suitable growing media or substrate is required. With keeping this all in mind, objectives of our investigations is to select a suitable growing substrate for greenhouse vegetable production.

The choice of a low-cost, good-quality growing substrate is vital to organic greenhouse vegetable production. Growing media are made of engineered materials designed to provide ideal physical and chemical characteristics for the root environment. In greenhouse agriculture, it is important that the substrate has good structural characteristics so it can hold up to frequent irrigation, root growth, drastic changes in temperature, $\mathrm{pH}$ and $\mathrm{EC}$ over the life of the crop. 


\section{Materials and Methods}

Study Area: The study was carried out in VNR Seeds Pvt. Ltd., in village Gomchi near Nandanvan of Raipur district in Chhattisgarh. In order to manipulate temperature, controlled environment in greenhouse was used. Good nursery hygiene is essential if disease free seedlings are to be produced for transplanting in the field. In some circumstances it may be advisable to treat the seed for diseases by using a seed coating treatment if this has not already been done by the seed supplier.

\section{Technical Specification}

\section{Variety \\ Scientific name \\ Sowing period: Harvest:}

Seed quantity per acre

Sowing distance between rows:

Sowing distance between plants:

\section{Procedure of work}

\section{Substrate preparation}

Different substrate used are-

- $100 \%$ cocopeat

- $100 \%$ peatmoss

- Mixture of $50 \%$ cocopeat and $50 \%$ peatmoss and

- Mixture of $60 \%$ cocopeat and $40 \%$ vermiculite

Firstly all the substrate was soaked in water for 12 hour, one day before seed sowing. One $\mathrm{kg}$ of cocopeat absorbs 7-8 times of water from its weight. Peat moss has ability to absorb 10- 20 times of water from its weight. Vermiculite absorbs 57 times of water.

\section{Sowing of material}

The brinjal seed (variety, VNR-212) were sown in this substrate on $2^{\text {nd }}$ August 2015. Four plastic trays, one having 221 cells (17 rows, 13 columns) are used for seed sowing. Each cell is $2 " \times 2$ " in size. Soaked substrate are placed in different tray in different proportion as required. It is irrigated with cold water to decrease the temperature of substrate. Not too much apply the water.

\section{Covering of containers $\&$ placing in germination room}

After sowing the seeds, trays were covered with polythene sheets and placed in germination chamber at $25^{\circ} \mathrm{C}$. Here it is kept for 3 to 4 days until seedlings come out from seeds.

\section{Removing from germination room\& placing into greenhouse}

When first radicle comes out of size approx. 1-2 cm then removes it from germination room and rapidly transfers it into the greenhouse for better growth of seedlings in controlled environment. The temperature and relative humidity is maintained at $30{ }^{\circ} \mathrm{C}$ and $35 \%$ respectively.

Irrigation: After getting two cotyledon leaves, irrigate fully. The seedling was under irrigation. Water used for irrigation was drawn from a water tank. Use only quality water low in salt. Disease organisms may survive in water, so the source of the water must be considered carefully. Water should not be recycled due to the risk of infecting plants with diseases.

\section{Fertigation}

When first true leaf is started to seen, means this is the end of germination stage and it is the time to start fertigation. Fertigation is provided three times a day. Ratio of NPK which is used for fertigation is $2: 1: 3$.

\section{First observation of seedlings}

First observation of seedlings was taken on $17^{\text {th }}$ August 2015, $15^{\text {th }}$ days after sowing the seed. Stem width, stem height, leaf width, leaf length, number of leaves and colour of leaves is observed and reading is taken (Table 1).

\section{Second observation of seedlings}

Second observation of seedlings was taken on $27^{\text {th }}$ August $2015,8^{\text {th }}$ days after first observation. Stem width, stem height, leaf width, leaf length, number of leaves and colour of leaves is observed and reading is taken (Table 2).

\section{Physical and chemical properties of soil-less substrate}

The substrate properties that influence seedling growth can be divided into physical properties (water-holding capacity, porosity, plasticity and bulk density) and chemical properties (fertility, acidity and cation exchange capacity).

Table 1: Bulk density and porosity of some growing substrate widely used in greenhouse and nursery crops.

\begin{tabular}{|c|c|c|}
\hline Substrate & Bulk density $(\mathbf{k g} / \mathbf{m 3})$ & Total porosity $(\% \mathbf{v} / \mathbf{v})$ \\
\hline Peat moss & $60-100$ & $90-95$ \\
\hline Dark peat & $100-150$ & $85-90$ \\
\hline Vermiculite & $90-150$ & $90-95$ \\
\hline Perlite & $80-120$ & $85-90$ \\
\hline Rockwool & $80-90$ & $94-97$ \\
\hline Cocopeat & $118-126$ & $94-96$ \\
\hline Ideal & $190-700$ & $50-85$ \\
\hline
\end{tabular}

Table 2: Cation exchange capacity and $\mathrm{pH}$ value of some substrates

\begin{tabular}{|c|c|c|c|c|c|}
\hline Material & $\begin{array}{c}\text { Cation } \\
\text { Exchange }\end{array}$ & $\begin{array}{c}\text { pH } \\
\text { values }\end{array}$ & $\begin{array}{c}\text { Water } \\
\text { Holding } \\
\text { Capacity }\end{array}$ & Weight & Cost \\
\hline Soil & Poor & $4.5-6.0$ & Poor & Heavy & Low \\
\hline Peat moss & Fair & $3.5-4.0$ & High & Lightweight & Medium \\
\hline Bark & High & $4.0-5.0$ & Medium & $\begin{array}{c}\text { Medium to } \\
\text { Heavy }\end{array}$ & Low \\
\hline Sand & Poor & $4.5-6.0$ & Poor & Heavy & Low \\
\hline Perlite & None & $6.0-8.0$ & Poor & $\begin{array}{c}\text { Very } \\
\text { Lightweight }\end{array}$ & High \\
\hline Vermiculite & High & $4.0-5.0$ & Good & $\begin{array}{c}\text { Very } \\
\text { Lightweight }\end{array}$ & High \\
\hline Compost & High & $4.5-6.0$ & good & Medium & Low \\
\hline
\end{tabular}

\section{Results and Discussion \\ Growth of seedlings in different substrate $100 \%$ Cocopeat}

The seeds were sown in this substrate on $2^{\text {nd }}$ August 2015. Four plastic trays, one having 221 cells (17 rows, 13 columns) are used for seed sowing. The average physical characteristics are stem width $2 \mathrm{~mm}$; stem length $59 \mathrm{~mm}$, leaf width $33 \mathrm{~mm}$, leaf length $42 \mathrm{~mm}$ and no. of leaves 4.6. The results of growth of seedlings in $100 \%$ cocopeat is shown in table 3

After 10 days of first observation, average physical characteristics are stem width $3.33 \mathrm{~mm}$; stem length $108 \mathrm{~mm}$, leaf width $42.33 \mathrm{~mm}$, leaf length $56.66 \mathrm{~mm}$ and no. of leaves 5.66. Results of second observation are shown in table 4. 


\section{$100 \%$ Peat moss}

The seeds were sown in this substrate on $2^{\text {nd }}$ August 2015. Four plastic trays, one having 221 cells (17 rows, 13 columns) are used for seed sowing. The average physical characteristics are stem width $1.66 \mathrm{~mm}$; stem length $43.33 \mathrm{~mm}$, leaf width 24 $\mathrm{mm}$, leaf length $34.66 \mathrm{~mm}$ and no. of leaves 4 . The results of growth of seedlings in $100 \%$ peat moss is shown in table 3 After 10 days of first observation, average physical characteristics are stem width $3 \mathrm{~mm}$; stem length $91.33 \mathrm{~mm}$, leaf width $33 \mathrm{~mm}$, leaf length $53.33 \mathrm{~mm}$ and no. of leaves 5 . Results of second observation are shown in table 4.

\section{$\mathbf{5 0} \%$ Cocopeat $+\mathbf{5 0} \%$ Peat moss}

The seeds were sown in this substrate on $2^{\text {nd }}$ August 2015. Four plastic trays, one having 221 cells (17 rows, 13 columns) are used for seed sowing. Average physical characteristics are stem width $2 \mathrm{~mm}$; stem length $55 \mathrm{~mm}$, leaf width $33.66 \mathrm{~mm}$, leaf length $38.33 \mathrm{~mm}$ and no. of leaves 4 . The results of growth of seedlings in $50 \%$ cocopeat and $50 \%$ peat moss is shown in table 3.

After 10 days of first observation, average physical characteristics are stem width $3.16 \mathrm{~mm}$; stem length 100.33 $\mathrm{mm}$, leaf width $42.33 \mathrm{~mm}$, leaf length $49.66 \mathrm{~mm}$ and no. of leaves 5 . Results of second observation are shown in table 4 .

\section{$60 \%$ Cocopeat $+40 \%$ Vermiculite}

The seeds were sown in this substrate on $2^{\text {nd }}$ August 2015. Four plastic trays, one having 221 cells (17 rows, 13 columns) are used for seed sowing. Average physical characteristics are stem width $0.4 \mathrm{~mm}$; stem length $29.66 \mathrm{~mm}$, leaf width 23.66 $\mathrm{mm}$, leaf length $26.66 \mathrm{~mm}$ and no. of leaves 3.66.The results of growth of seedlings in $60 \%$ cocopeat and $40 \%$ vermiculite is shown in table 3 .

After 10 days of first observation, average physical characteristics are stem width $2 \mathrm{~mm}$; stem length $64 \mathrm{~mm}$, leaf width $35.66 \mathrm{~mm}$, leaf length $48 \mathrm{~mm}$ and no. of leaves 5 . Results of second observation are shown in table 4.

From considering both observations table 3 and 4 and graphs fig 1 and fig 2, growth of seedlings in the tray with only cocopeat is better comparison to other substrates and growth of seedlings in mixture of cocopeat and vermiculite is poor. Observing the growth of seedlings in different substrate we can say that cocopeat is best growing substrate among all substrates we used. After that mixture of $50 \%$ cocopeat and $50 \%$ peat moss provides better results. Fig 3 shows the difference in growth of seedlings of different substrates.

Table 3: Data of first observation on 17/08/2015

\begin{tabular}{|c|c|c|c|c|c|}
\hline Substrate & Stem Width $(\mathbf{m m})$ & Stem Length $(\mathbf{m m})$ & Leaf Width (mm) & Leaf Length (mm) & Number of Leaves \\
\hline 100\% COCOPEAT & 2 & 59 & 33 & 42 & 4.6 \\
\hline 100\% PEATMOSS & 1.66 & 43.33 & 24 & 34.66 & 4 \\
\hline 50\% COCOPEAT + 50\% PEATMOSS & 2 & 55 & 33.66 & 38.33 & 4 \\
\hline 60\% COCOPEAT + 40\% VERMICULITE & 0.4 & 29.66 & 23.66 & 26.66 & 3.66 \\
\hline
\end{tabular}

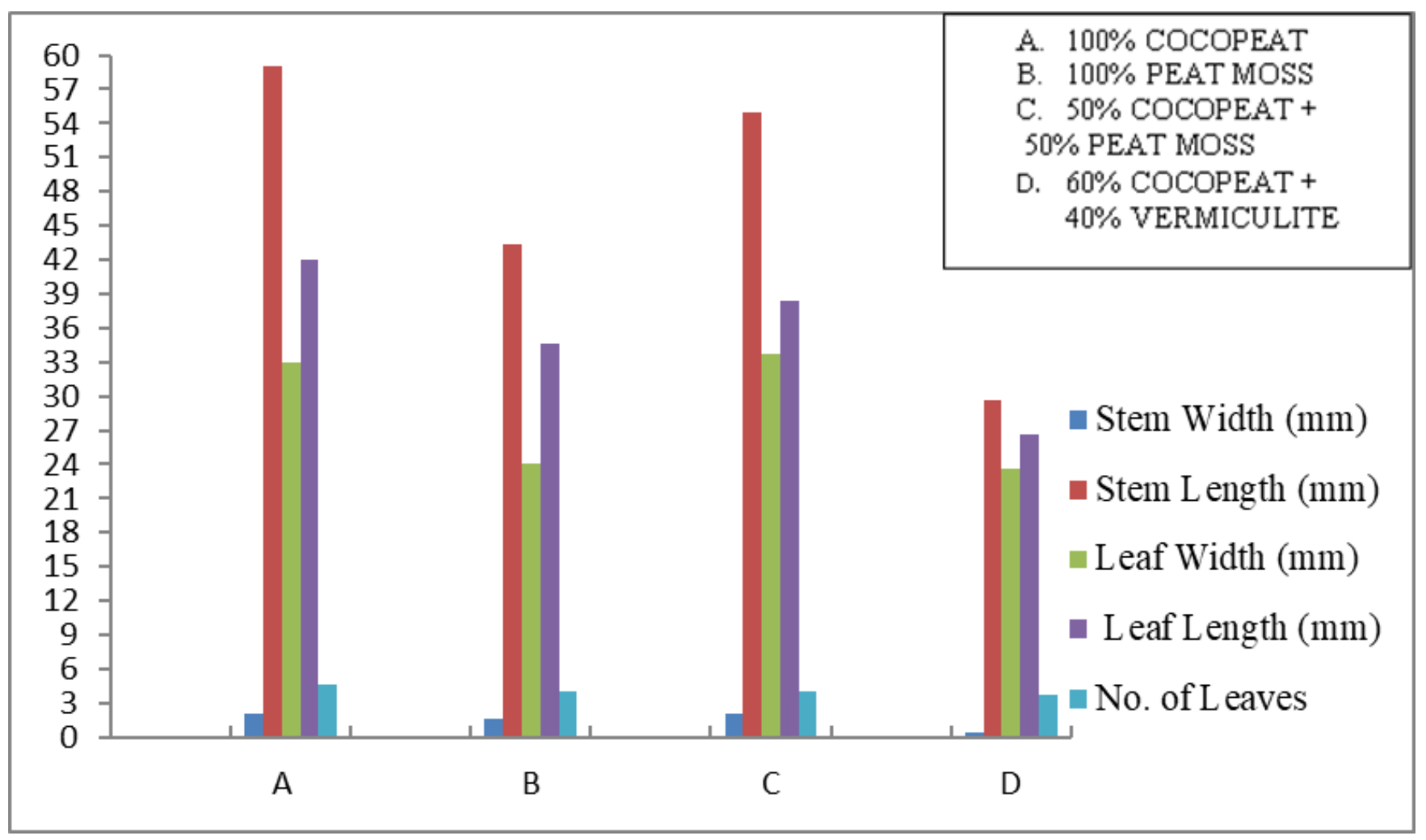

Fig 1: Graphical representation of $1^{\text {st }}$ observation after 10 days of germination

Table 4: Data of second observation on 27/08/2015

\begin{tabular}{|c|c|c|c|c|c|}
\hline Substrate & Stem Width $(\mathbf{m m})$ & Stem Length $(\mathbf{m m})$ & Leaf Width $(\mathbf{m m})$ & Leaf Length (mm) & Number of Leaves \\
\hline 100\% COCOPEAT & 3.33 & 108 & 42.33 & 56.66 & 5.66 \\
\hline 100\% PEATMOSS & 3 & 91.33 & 33 & 53.33 & 5 \\
\hline 50\% COCOPEAT+ 50\% PEATMOSS & 3.16 & 100.33 & 42.33 & 49.66 & 5 \\
\hline 60\% COCOPEAT+ 40\%VERMICULITE & 2 & 64 & 35.66 & 48 & 5 \\
\hline
\end{tabular}




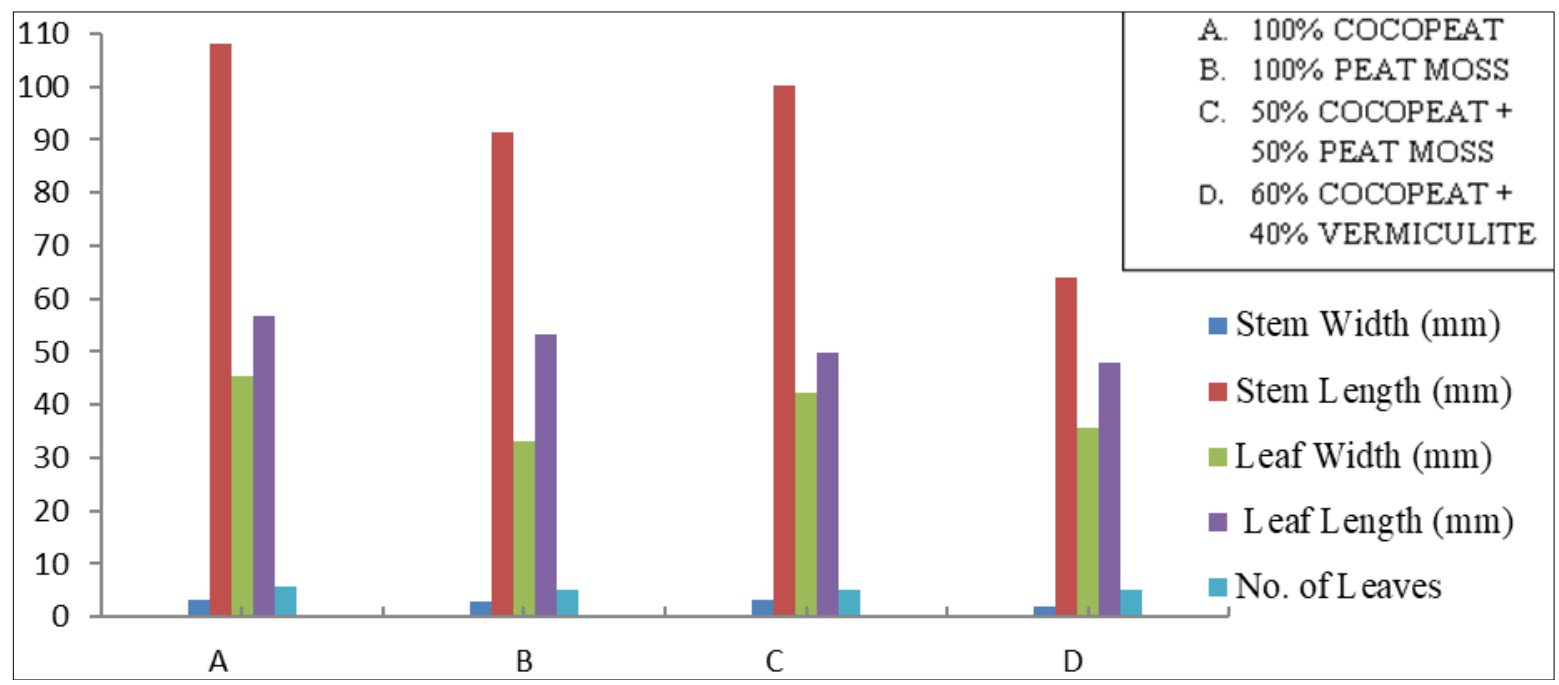

Fig 2: Graphical representation of $2^{\text {nd }}$ observation after 20 days of germination

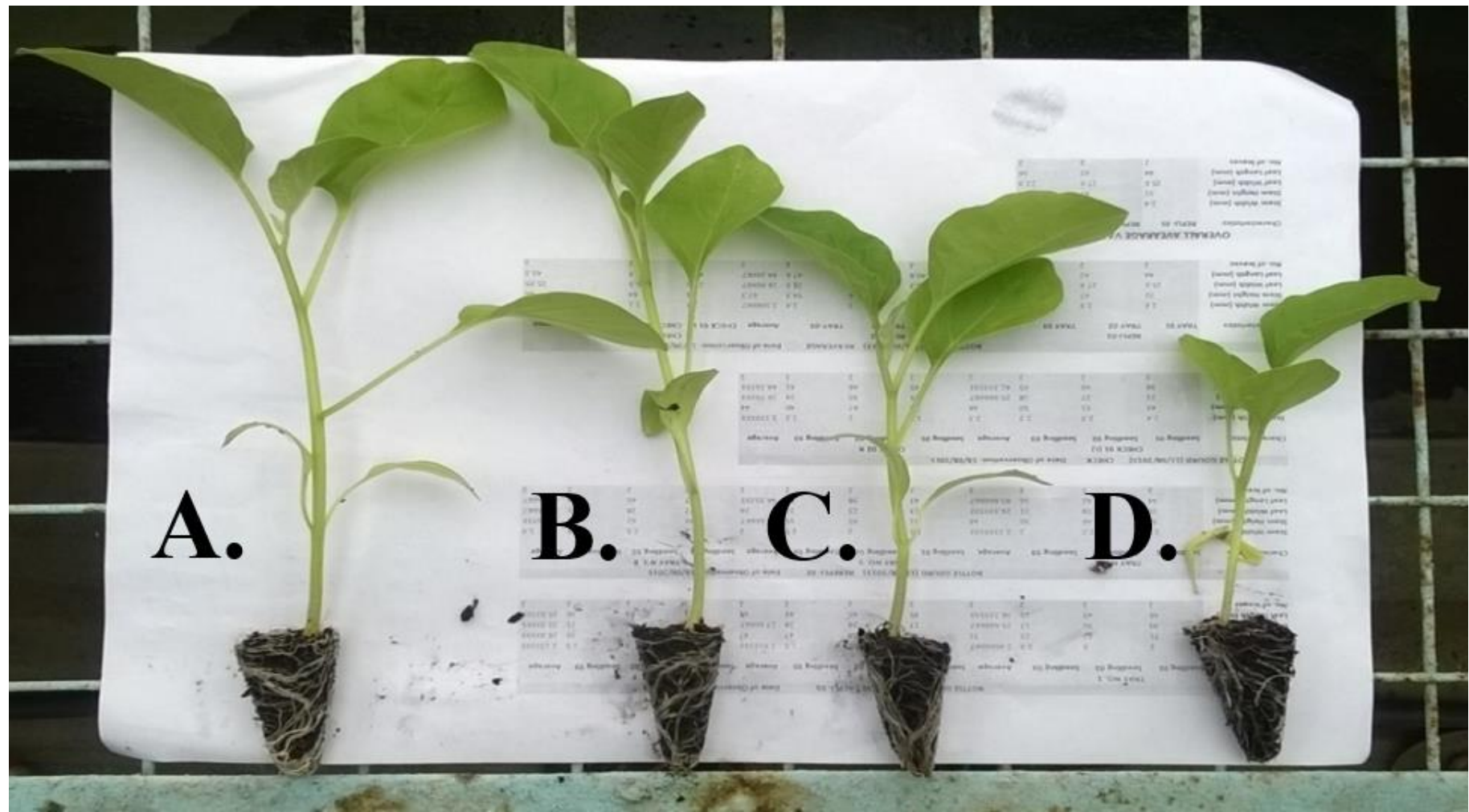

a. $100 \%$ Cocopeat

b. $50 \%$ Cocopeat $+50 \%$ Peatmoss

c. $100 \%$ Peatmoss

d. $60 \%$ Cocopeat $+40 \%$ Vermiculite

Fig 3: Comparison of growth of seedlings in different media

\section{Conclusions}

Use of suitable growing media or substrates is essential for production of quality horticultural crops. It directly affects the development and later maintenance of the extensive functional rooting system. A good growing medium would provide sufficient anchorage or support to the plant, serves as reservoir for nutrients and water, allow oxygen diffusion to the roots and permit gaseous exchange between the roots and atmosphere outside the root substrate. Top soil is used as a part of growing medium by many nurserymen. It is a nonrenewable resource. Increasing utilization of available land for physical and infrastructural development rapidly declines the supply of quality topsoil and thus promoting the utilization of soilless materials in the production of horticultural crops.
A good growing medium would provide sufficient support to the plant. Sturdy growth of seedlings is obtained in tray with cocopeat and tray with mixture of $50 \%$ cocopeat $\& 50 \%$ peat moss. Growth of seedlings in the tray with only cocopeat is better comparison to other substrates and growth of seedlings in mixture of cocopeat and vermiculite is poor. Observing the growth of seedlings in different substrate we can say that cocopeat is best growing substrate among all substrates we used. After that mixture of $50 \%$ cocopeat and $50 \%$ peat moss provides better results.

\section{References}

1. Abouzari A, Rouhi S, Eslami A, Kaviani B. Comparison of the effect of different soilless growing media on some growth characteristics of benjamin tree (Ficus 
benjamina). International Journal of Agriculture and Biology, 2012, 14(6).

2. Asgharipour MR. Effects of planting depth on germination and the emergence of field Bindweed (Convolvulus arvensis L.). Asian Journal of Agricultural Sciences. 2011; 3(6):459-461.

3. Bhat N, Albaho M, Suleiman M, Thomas B, George P, Ali SI. Growing substrate composition influences growth, productivity and quality of organic vegetables. Asian J Agric. Sci. 2013; 5(4):62-66.

4. Verhagen JBGM, Blok C. Trends in rooting media in Dutch horticulture during the period 2001-2005: The new growing media project. In International Symposium on Growing Media. 2007; 819:47-58.

5. Ebrahimi R, Souri MK, Ebrahimi F, Ahmadizadeh M. Growth and yield of strawberries under different potassium concentrations of hydroponic system in three substrates. World Appl. Sci. J. 2012; 16(10):1380-1386.

6. Fitzpatrick GE. Compost utilization in ornamental and nursery crop production systems. Compost utilization in horticultural cropping systems. New York: Lewis Publishers, 2001, 135-150.

7. Ibrahim HM, Olasantan FO, Oyewale RO. Age of seedling at transplanting influenced growth and fruit yield of sweet pepper (Capsicum annum L. cv. Rodo). Net Journal of Agricultural Science. 2013; 1(4):107-110.

8. Jensen MH, Rorabaugh PA, Garcia AM. Comparing five growing media for physical characteristics and tomato yield potential. Proc. of Am. Soc. Plasticulture. 1998; 27:31-34.

9. Nazari F, Farahmand H, Khosh-Khui M, Salehi H. Effects of coir as a component of potting media on growth, flowering and physiological characteristics of hyacinth (Hyacinthus orientalis L. cv. Sonbol-eIrani). International Journal of Agriculture and Food Science. 2011; 1:34-38.

10. Oberpaur C, Puebla V, Vaccarezza F, Arévalo ME. Preliminary substrate mixtures including peat moss (Sphagnum magellanicum) for vegetable crop nurseries. Ciencia e investigación agrarian. 2010; 37(1):123-132.

11. Olle M, Ngouajio M, Siomos A. Vegetable quality and productivity as influenced by growing medium: a review. Agriculture. 2012; 99(4):399-408.

12. Schroeder FG, Sell H. September. Use of compost made from livestock manure as an organic substrate for cucumber (Cucumis sativus L.) grown in greenhouse. In International Symposium on Growing Media 2007; $819: 367-372$.

13. Shanmugasundaram R, Jeyalakshmi T, Mohan SS, Saravanan M, Goparaju A, Murthy PB. Coco peat-An alternative artificial soil ingredient for the earthworm toxicity testing. Journal of Toxicology and Environmental Health Sciences. 2014; 6(1):5-12.

14. Treder J. The effects of cocopeat and fertilization on the growth and flowering of oriental lily 'star gazer'. Journal of Fruit and Ornamental Plant Research. 2008; 16:361370.

15. Vaughn SF, Deppe NA, Palmquist DE, Berhow MA. Extracted sweet corn tassels as a renewable alternative to peat in greenhouse substrates. Industrial crops and products. 2011; 33(2):514-517.

16. Wilson SB, Stoffella PJ, Graetz DA. Compost amended media and irrigation system influence containerized perennial Salvia. Journal of the American Society for Horticultural Science. 2003; 128(2):260-268. 